\title{
ARBEJDET MED AT OPTIMERE ARBEJDET \\ Human resource management som optimering af optimering
}

\author{
CHRISTIAN T. LYSTBÆEK
}

I denne artikel vil jeg analysere arbejdet med at optimere arbejdet. Optimeringsprocesser $i$ arbejdslivet har længe været genstand for samfunds- og humanvidenskabelige analyser, særligt inden for sociologien (for eksempel Grint 2005; Vallas et al. 2009) og psykologien (for eksempel Muchinsky 2008; Schultz \& Schultz 2009). Disse analyser har hovedsageligt fokuseret på, hvordan den fortsatte bestræbelse på optimering af produkter og produktionsformer har haft afgørende betydning for menneskers hverdagsliv og selvforståelse, både på og uden for arbejdet. Det gælder i særlig grad i kapitalistiske samfund, der er karakteriseret ved en fortsat stræben efter profit og økonomisk vækst (Davies 1996; Cunliffe 2009). På denne baggrund har analyserne ofte betonet de positive aspekter ved optimering i form af teknologisk og økonomisk udvikling. Eksempelvis fremhæver mange analyser, at dette har bidraget til forbedringer af det fysiske og psykiske arbejdsmiljø (Price 2007, 2011) og dagligdagen i det hele taget (Applebaum 1992; Davies 1996). På baggrund af sådanne positive analyser har optimeringsbestræbelsen de seneste år fået stor politisk opmærksomhed og tilslutning, blandt andet i form af en produktivitetskommission, der har givet en række bud på, hvordan produktiviteten i samfundet kan optimeres yderligere. Men vi har også fået analyser, der har betonet negative aspekter ved fortsat optimering, både for miljøet og for mennesker. Eksempelvis er det blevet fremhævet, at den fortsatte optimering ikke kun har medført forbedringer, men også forværringer for det fysiske og psykiske arbejdsmiljø (for eksempel Lundberg \& Cooper 2010) og for miljøet i det hele taget (for eksempel Blowfield 2013). Endvidere fremfører nogle forskere, at den fortsatte optimering har medført en forbrugerkultur, der risikerer at forarme menneskets hverdagsliv og sociale relationer (Durning 1992; Barber 2008). Herhjemme har antropologiske studier bidraget til at fremhæve disse negative aspekter. Eksempelvis har Kirsten M. Bovbjerg analyseret, hvordan nye ledelsesformer involverer nye subtile former for disciplinering af med- 
arbejderne (Bovbjerg 2001), og Jakob Krause-Jensen har analyseret, hvordan nye ledelsesformer medfører utilsigtet forvirring blandt medarbejderne (KrauseJensen 2010). Bovbjerg og Krause-Jensen har yderligere været med til at analysere oplevelsen af stress som følge af nye ledelses- og organiseringsformer på en række forskellige arbejdspladser (Bovbjerg et al. 2011).

I denne artikel vil jeg i forlængelse af den antropologiske litteratur analysere bestræbelserne på at optimere arbejdet, som de kommer til udtryk i litteraturen om personaleledelse eller human resource management (herefter HRM). ${ }^{1} \mathrm{HRM}-$ litteraturen er omfattende og viser, at arbejdet med at optimere de menneskelige ressourcer i arbejdet beskrives på forskellige måder. Det er imidlertid blevet udbredt at betone, at der overordnet set kan identificeres to forskellige strategier $\mathrm{i}$ HRM, som typisk betegnes henholdsvis „hård“ og „blød“ HRM (for eksempel Storey 1992) eller en henholdsvis ,high performance" og ,high commitment" HRM (for eksempel Legge 2005). ${ }^{2}$ Den såkaldt , hårde“ "strategi søger at optimere de menneskelige ressourcer med fokus på at $u$ dnytte dem bedst muligt for at skabe så høj en grad af produktivitet som muligt, mens den såkaldte „bløde“ strategi søger at optimere de menneskelige ressourcer med fokus på at $u d v i k l e$ dem bedst muligt for at skabe så høj en grad af engagement som muligt. I denne artikel vil jeg pege på, at en ensidig fokusering på denne modstilling overser, at fokus i HRMstrategierne er blevet forskudt, så de efterhånden omfatter stadig flere menneskelige ressourcer. Med andre ord har „optimering af arbejdet“ ikke en fast betydning eller definition, men gives forskellige betydninger i den løbende bestræbelse på at optimere HRM, det vil sige optimere arbejdet med at optimere arbejdet.

Jeg vil analysere forskydningerne i HRM som udtryk for en 2.-ordensoptimeringsbestræbelse, det vil sige en løbende optimering af optimering af arbejdet. Formålet hermed er at bidrage til at nuancere forståelsen af HRM-feltets kompleksitet, karakteriseret ved mange forskellige forståelsesrammer og praksisformer i forhold til at optimere menneskelige ressourcer $i$ arbejdet.

Med dette analytiske blik knytter jeg i artiklen an til Foucault-inspirerede diskursanalyser af HRM, som man finder hos blandt andre Barbara Townley (1994) og herhjemme hos Niels Åkerstrøm Andersen (2004, 2012), men jeg specificerer disse analyser ved at fokusere på optimeringsbestræbelsen $\mathrm{i}$ HRM. Hertil inddrager jeg HRM-politikker fra to danske kommuner, Sorø Kommune og Herning Kommune. Disse politikker er typisk blevet diskuteret og vedtaget $i$ enighed mellem organisationens forskellige parter i organisationens hovedsamarbejdsudvalg.

Min analyse kan således betegnes som en del af den form for ,,anthropology of policy“, som Shore og Wright (1997) formulerer rammerne for. Som Shore og Wright betoner, er politikker og principper i stigende grad blevet udgangspunkt 
for kulturelle praksisformer i arbejdslivet og samfundslivet i øvrigt, hvor de i kraft af deres præskriptive fordringer og normative antagelser bidrager til at forme forståelsesrammerne for sociale relationer (Shore \& Wright 1997:6). På denne baggrund opfordrer de til antropologiske analyser, der anskuer principper og politikker som antropologiske data, der kan analyseres med henblik på at afdække de semantikker og teknikker, der bringes i spil, samt de præskriptive fordringer og normative antagelser, som dette medfører (Shore \& Wright 1997: $7 \mathrm{ff}$.). Det er denne opfordring, jeg vil følge i artiklen.

I det følgende vil jeg først redegøre for de overordnede strategier i arbejdet med at optimere arbejdet, som HRM-litteraturen beskriver som „hård“ og „blød“ HRM, og de grundlæggende antagelser om ledelse, som disse beror på. Herefter vil jeg nuancere denne simple modstilling ved at identificere en række semantiske forskydninger i HRM-feltet. Jeg vil pege på, at man i HRM-principper og politikker kan identificere (mindst) fire forskellige semantikker om optimering af de menneskelige ressourcer: en økonomisk, en juridisk, en emotionel og en pædagogisk semantik. Disse semantikker tilbyder konkrete begreber og praktiske greb i forhold til arbejdet med at optimere de menneskelige ressourcer i arbejdet - og i det hele taget.

\section{Strategier i HRM}

I forbindelse med strukturreformen i 2007, der medførte etableringen af nye, større kommuner, formulerede mange af de nye kommuner visioner og strategiske mål for deres HRM-arbejde. Eksempelvis har Sorø Kommune formuleret en vision for kommunen som arbejdsplads, der betoner, at ,medarbejdere og ledere udgør en afgørende ressource for at kunne levere god borgerservice" (Sorø Kommune 2007: 1). En tilsvarende vision er formuleret i Herning Kommune, der i en politik for kompetenceudvikling af medarbejderne $\mathrm{i}$ kommunen betoner, at ,de menneskelige ressourcer og kvalifikationer tillægges stadig stigende betydning i bevarelse og udvikling af den danske velfærd. De opgaver, der skal løses, kravene til udvikling, nytænkning og effektivitet på Herning Kommunes arbejdspladser bliver stadig mere krævende. Derfor er indsatsen for at udvikle dine kompetencer, så de kan matche disse krav, så vigtig“" (Herning Kommune 2007a:1).

Kommunerne står ikke alene med denne betoning af vigtigheden af de menneskelige ressourcer i organisationen. I dag er det blevet et mantra i HRMfeltet, at de ansatte er virksomhedens mest dyrebare ressource. Baggrunden for denne betoning af vigtigheden af de menneskelige ressourcer i virksomheder og organisationer er, at mennesker, det vil sige arbejdskraften, efterhånden er blevet en vigtigere ,produktionsfaktor“" end andre faktorer som råvarer, teknologier osv. 
Uden menneskelige ressourcer til at bearbejde råvarer og betjene teknologier er der ingen produktion og slet ingen optimering af produkter eller produktivitet.

Optimering af de menneskelige ressourcer er således et centralt aspekt $\mathrm{i}$ bestræbelsen på at optimere såvel produkter som produktivitet. Det gælder i særlig grad for videns-, service- og administrative organisationer, der ikke altid producerer et fysisk produkt, eksempelvis når det handler om udvikling i en udviklingsafdeling eller marketing i en salgsafdeling i private virksomheder, eller når det handler om sagsbehandling i en teknisk forvaltning eller undervisning på en skole i kommunerne.

Men de menneskelige ressourcer er ikke alene de mest dyrebare, de er også de dyreste ressourcer i mange virksomheder og organisationer, i særdeleshed i kommunale organisationer, hvor lønbudgettet ofte er blandt de største udgiftsposter. Derfor er der igennem tiden blevet udviklet en række tiltag og teknikker til optimering af de menneskelige ressourcer i arbejdet. Dette arbejde med at optimere arbejdet er blevet stadig mere specialiseret og professionaliseret fra 1900-tallets begyndelse, hvor ledelse voksede frem som en specialiseret fagdisciplin (Drucker 1973; Legge 2005).

\section{Udviklingen af HRM som ledelsesdisciplin}

Frederick Taylor beskrives typisk som en af fædrene til ledelse som faglig og professionel disciplin (Bakke \& Fivelsdal 2002). Og Taylors beskrivelser af ledelse i bøgerne Shop Management (1903) og The Principles of Scientific Management (1911) udgør da også et gennembrud for det systematiske og strategiske fokus på at optimere de menneskelige ressourcer i arbejdet. I disse værker betoner Taylor, at man kan optimere de menneskelige ressourcer i arbejdet gennem ledelsestiltag såsom klare funktionsbeskrivelser og belønningssystemer samt systematisk rekruttering og oplæring til disse funktioner. Men mest kendt er Taylors betoning af standardisering af arbejdsprocesserne. Taylor anbefalede systematiske tidsog bevægelsesstudier af alle arbejdsgange med henblik på at optimere disse ved at reducere tidsforbruget og al unødvendig fysisk bevægelse. Denne form for optimering af arbejdsgange er i dag blevet en selvfølgelig del af mange former for industriel samlebåndsproduktion, men den har også bredt sig til andre former for standardiseret arbejde såsom rengøring og fastfoodproduktion. Ford og McDonalds har for eksempel haft stor succes med at optimere arbejdsgange i form af standardiseret samlebåndsproduktion. Derfor er dette fokus i dag mest kendt som „fordisme“ eller „mcdonaldisering“ (Cunliffe 2009).

Taylors principper for rationel ledelse er som nævnt blevet en selvfølge i industriel produktion og andre steder. De er blevet videreført og videreudviklet 
i moderne ledelseskoncepter, eksempelvis lean management, der har fokus på at optimere arbejdet gennem reduktion af spild og unødvendige arbejdsgange, eller performance management, der har fokus på at optimere arbejdet gennem $\mathrm{p}$ ræstationsmålingssystemer og belønningssystemer.

Men efterhånden har disse principper om optimering af de menneskelige ressourcer vist sig ikke at være tilstrækkelige og nogle gange slet ikke nødvendige, men tværtimod kontraproduktive i forhold til at optimere arbejdet (Legge 2005; Guest et al. 2013). Således er betoningen af optimering af de menneskelige ressourcer gennem standardisering og effektivisering blevet kritiseret for at reducere de menneskelige ressourcer til en komponent $i$ en maskine, det vil sige et sæt af funktioner og standardiserede bevægelser, som kan styres og kontrolleres efter rationelle kriterier (Bakka \& Fivelsdal 2002). Men de menneskelige ressourcer kan være andet og mere end en komponent i en maskine. Endvidere har standardisering og effektivisering vist sig i nogle tilfælde at føre til suboptimering snarere end optimering, det vil sige optimering i forhold til en enkelt delopgave eller delfunktion, men ikke i forhold til det overordnede produkt eller den samlede produktivitet i en virksomhed (Legge 2005). Endelig har det vist sig, at standardisering og effektivisering kan medføre optimering på kort sigt, der på længere sigt kan vise sig at være kontraproduktiv. Eksempelvis har det vist sig, at ensartede bevægelser med høj intensitet er nedslidende og demotiverende for mange mennesker. På længere sigt kan standardisering og effektivisering af arbejdsgange således føre til højt sygefravær, dårligt arbejdsmiljø, stor personaleudskiftning osv. (Legge 2005). Derfor kan optimering af de menneskelige ressourcer gennem standardisering og effektivisering vise sig at være kontraproduktiv.

Det såkaldte human relations-paradigme markerer et gennembrud for denne pointe om, at standardisering og effektivisering kan være kontraproduktiv (Bovbjerg 2001). Dette paradigme bygger på erfaringer fra studier af trivsel og samarbejde, blandt andet på de store elektronikfabrikker i Hawthorne i 1920'erne, der viste, at „bløde“ aspekter som trivsel og samarbejde er centrale aspekter ved de menneskelige ressourcer (Bakka \& Fivelsdal 2002). Disse aspekter er blevet stadig mere betonet, efterhånden som traditionelle produktionsvirksomheder er blevet suppleret med videns-, service- og administrative organisationer. Disse organisationer er ikke kendetegnet ved at bearbejde råvarer til standardiserede produkter. I det hele taget er der ikke altid et fysisk produkt, men et "produkt“ i form af service eller viden, som det ofte er tilfældet i kommunale organisationer. I denne form for arbejde går optimering af de menneskelige ressourcer ikke altid gennem standardisering og effektivisering, men snarere gennem motivation og inspiration. Det gælder i særlig grad, når videns- eller servicearbejdet involverer 
udvikling og innovation, der sjældent lader sig reducere til standardiserede arbejdsgange.

I dag står vi således med en sammensat og modsætningsfuld forståelse af HRM, der omfatter både kortsigtede og langsigtede strategier i forhold til såvel effektiv drift som konstruktiv udvikling i virksomheder og organisationer.

\section{„Hård“ og „blød“ HRM}

Det modsætningsfyldte i arbejdet med at optimere de menneskelige ressourcer i arbejdet kan også identificeres i HRM-litteraturen, der som nævnt betoner, at der overordnet set kan identificeres to forskellige strategier i arbejdet med at optimere arbejdet.

John Storey (1992) har betegnet disse to forskellige strategier i HRM som henholdsvis ,hård“ og „blød“ HRM. En „,hård“ tilgang til HRM finder man hos den såkaldte michiganskole (Fombrun et al. 1984), der betoner, at arbejdskraft er et middel til at opnå resultater og som sådan skal ledes som alle andre ressourcer i en organisation. Ifølge denne tilgang er formålet med HRM at udnytte alle ressourcer i organisationen mest effektivt. De systemer i en organisation, der skal bidrage hertil, er systemer til udvælgelse, vurdering, fastholdelse, belønning og kompetenceudvikling af medarbejderne. Som sådan har denne tilgang træk til fælles med filosofien i scientific management. Den hårde version af HRM lægger ligesom scientific management stor vægt på kvantitative og kalkulative aspekter ved ledelse af de menneskelige ressourcer, hvorfor der fokuseres på arbejdstilrettelæggelse, planlægning, målinger osv. Karen Legge betoner, at ledelsesfilosofien bag denne HRM-strategi er utilitaristisk-instrumentalistisk, det vil sige en tænkning med fokus på nyttemaksimering, hvor de menneskelige ressourcer betragtes som et centralt middel hertil. På denne baggrund betegner hun tilgangen som fokuseret på ,high performance“ (Legge 2005).

En anden og mere „blød“ tilgang til HRM finder man hos den såkaldte harvardskole (Beer et al. 1985), der betoner, at mennesket er en særlig og speciel ressource i organisationer, som ikke kan sidestilles med andre ressourcer. Formålet med HRM er at udvikle denne ressource først og fremmest ved at skabe engagement og samarbejde. Det antages, at engagement (commitment) hos medarbejderne og gode relationer (congruence) mellem ledelse og medarbejdere er afgørende for en succesfuld organisation. Som sådan har den bløde version af HRM mange træk til fælles med filosofien i human relations, hvor fokus er rettet mod, hvordan man kan fremme engagement og motivation hos medarbejdere. Den bløde version af HRM lægger ligesom human relations-tilgangen stor vægt på, at arbejdet skal være meningsfuldt og udviklende, og at forskellige medarbejdere kan have forskellige 
måder at løse opgaverne på. Hermed rettes fokus mod udviklingstiltag som meda rbejderudviklingssamtaler (MUS), coaching, teamsamarbejde, trivsel osv. Derfor betegnes denne tilgang til HRM til tider som human ressource development, HRD (Swanson \& Holton 2009). Legge beskriver ledelsesfilosofien bag denne tilgang til HRM som udviklingshumanistisk, det vil sige en tænkning med fokus på menneskets udvikling og motivation. På denne baggrund betegner hun tilgangen som fokuseret på „high commitment“" (Legge 2005).

I ledelsesteorien diskuteres „hård“ og „blød“ HRM som en sondring mellem to begreber for ledelse: management og leadership. Sondringen har i en del år været det helt centrale og gennemgående tema i ledelsesteori (Cunliffe 2009). Management handler om at effektivisere og trimme organisationens systemer, først og fremmest de systemer, som man inden for klassisk ledelsesteori forbinder med rationel ledelse: systematisk planlægning, budgettering, bemanding og belønning. Med dette fokus på effektiv styring og kontrol følger ofte et mekanistisk syn på, hvordan organisationer fungerer, et syn, der betoner strukturer og systemer. Leadership handler derimod om at motivere og inspirere medarbejderne, først og fremmest med henblik på at gøre arbejdet meningsfuldt og udviklende for medarbejderne. Med dette fokus på involvering og udvikling følger ofte et humanistisk syn på, hvordan organisationer fungerer - et syn, der betoner skabelsen af mening og motivation. Frem for at have fokus på strukturer og systemer er fokus rettet mod kommunikation, motivation og engagement, der kan udvikle potentialet hos medarbejderne. Hvor management har fokus på at optimere gennem brug af avancerede styrings- og kontrolsystemer, har leadership fokus på at optimere gennem brug af motivations- og meningsskabende tiltag, først og fremmest gennem involvering og uddelegering (Cunliffe 2009).

Denne modstilling mellem hård og blød HRM er relevant, fordi den peger på forskellige strategiske fokuspunkter med hensyn til optimering af de menneskelige ressourcer i virksomheder og organisationer. Men modstillingen indebærer ikke, at man skal vælge mellem den ene eller den anden. Bennis og Nanus (1985) betegner forskellen mellem management og leadership som en forskel i ledelsesfokus: Management har fokus på styring og kontrol (,to do things right“), mens leadership har fokus på mening og motivation (,to do the right things"). Men deres pointe er netop, at der ikke er meget ved at gøre tingene rigtigt, hvis man ikke gør de rigtige ting - og omvendt er der heller ikke meget ved at gøre de rigtige ting, hvis man ikke gør dem rigtigt. At gøre de rigtige ting og gøre dem rigtigt er således hinandens forudsætninger. Det kan illustreres ved, at der i alle organisationer er brug for både management og leadership, det vil sige både hård og blød HRM (Bennis \& Nanus 1985; Cunliffe 2009).

At mange organisationer forsøger at kombinere management og leadership, det vil sige hård og blød HRM, fremgår også af HRM-politikkerne fra henholdsvis 
Sorø Kommune og Herning Kommune. Eksempelvis betoner visionspapiret fra Sorø Kommune, at kommunen ønsker at være en stabil leverandør af kommunal service, som lever op til politikeres og borgeres forventninger (Sorø Kommune 2007:1), hvilket er et udtryk for hård HRM. Samtidig betoner visionspapiret dog også, at det er ,den rigtige sammensætning af de rigtige mennesker på det rigtige tidspunkt, som giver de unikke resultater - lig med den unikke borgerservice“ (Sorø Kommune 2007:1), hvilket er et udtryk for blød HRM. Denne dobbelthed kan også findes i HRM-politikkerne fra Herning Kommune. Eksempelvis betoner kommunens HRM-vision, at alle ledere og medarbejdere i Herning Kommune skal udvise „,konomisk sans" i form af ,økonomisk rettidig omhu“ og ,,prioritering på den bedst tænkelige måde“ (Herning Kommune 2007b), hvilket er et udtryk for hård HRM, men samtidig betoner visionen også, at alle ledere og medarbejdere har ,frihed til at udvikle sig [...] i et mangfoldigt arbejdsmiljø med høj motivation og trivsel“"(Herning Kommune 2007b), hvilket er et udtryk for blød HRM. HRMpolitikkerne fra henholdsvis Sorø Kommune og Herning Kommune viser således, at der er elementer af både hård og blød HRM til stede.

En simpel modstilling mellem hård og blød HRM kan tjene til at betone en grundlæggende modsætning i HRM-feltet, men en ensidig fokusering på denne modstilling overser, at fokus i HRM-strategierne er blevet forskudt, så de efterhånden omfatter stadig flere menneskelige ressourcer. Modstilling mellem to forskellige strategier repræsenterer ikke et reelt alternativ, men et strategisk dilemma. Endvidere er terminologien problematisk. Eksempelvis påpeger Clematide og Lassen, at „blød“, humanistisk HRM-retorik ofte „,forkortes til et fermt rationaliseringsinstrument under moderne produktionsbetingelser" (Clematide \& Lassen 1999:15). I overensstemmelse hermed påpeger Bovbjerg, at „blød“ humanistisk psykologi bruges til hård disciplinering (Bovbjerg 2001). Som sådan kan en „blød“" retorik dække over en „hård“ logik (Legge 2005).

Vi står således med en mere sammensat og modsætningsfuld forståelse af arbejdet med at optimere arbejdet i HRM end den simple modstilling mellem hård og blød HRM. I det følgende vil jeg identificere en række forskellige semantikker og teknikker i forhold til at optimere de menneskelige ressourcer i virksomheder og organisationer, som HRM-strategierne har udviklet sig igennem og fortsat trækker på i arbejdet med at optimere arbejdet i dag, men som den simple modstilling mellem hård og blød HRM ikke kan indfange.

\section{Semantikker i HRM}

HRM-litteraturen viser, at de overordnede strategier i HRM kan forstås og fremmes på forskellige måder. Med andre ord kan der i udviklingen og udbredelsen af 
HRM identificeres en række forskellige semantikker og teknikker, som arbejdet med at optimere arbejdet trækker på.

Nedenfor vil jeg vise, at man kan identificere (mindst) fire forskellige semantikker med tilhørende sæt af teknikker i arbejdet med at optimere arbejdet: en økonomisk, en juridisk, en emotionel og en pædagogisk semantik. Disse semantikker tilbyder hver især et sprog, hvori arbejdet med at optimere de menneskelige ressourcer formuleres og formes. De tilbyder således et sprog for arbejdet med at optimere arbejdet, der kan få store konsekvenser for forståelsen af, hvad det vil sige at være et menneske, nemlig en ressource, der kan optimeres i og for arbejdslivet.

\section{En økonomisk semantik om HRM}

Begrebet ,arbejde“ kan betyde mange forskellige ting (Arendt 1958; Applebaum 1992). I et historisk perspektiv har det først og fremmest været brugt til at betegne aktiviteter, som mennesker udøver for at forsørge sig selv og deres familie (Davies 1996). Som sådan er arbejde en grundlæggende økonomisk aktivitet eller funktion. Det er noget, man gør mod betaling eller anden form for belønning (Machin 2006).

Det gælder også arbejdet med at optimere arbejdet. Det er noget, man gør, fordi „det kan betale sig“, det vil sige, fordi udbyttet af arbejdet herved øges. Etymologisk betragtet henviser begrebet „økonomi“ til „husholdning“, mens begrebet „arbejde“ henviser til „møje og besvær“ og „pinsel“ (Arendt 1958). Som sådan er der en lang tradition for at forbinde arbejde med fysisk hårde og slidsomme aktiviteter, mens det $i k k e$ at arbejde er blevet forbundet med frihed (Arendt 1958; Applebaum 1992). Denne forståelse af arbejde kendes blandt andet stadig fra ordsprog som „man må yde, før man kan nyde“.

Denne forståelse af arbejde som noget negativt var særlig udbredt i antikken, hvor arbejde blev forbundet med slaveri. Arbejde var pr. definition slavearbejde og noget, som frie mennesker (det vil sige rige mænd) så vidt muligt undgik (Applebaum 1992). Arbejde blev forbundet med nødvendighed og som sådan med ufrihed, mens frihed blev forbundet med fri tid til at nyde konsumption og kontemplation. I antikken holdt frie mænd slaver, ikke så meget for den økonomiske vindings eller profittens skyld, men først og fremmest for selv at være fri for at arbejde, det vil sige fri for besværet med at producere til livets opretholdelse, noget, der blev betragtet som dyrisk og dermed som noget, frie mennesker skulle hæve sig over (Arendt 1958).

I forlængelse af denne negative betydning af begrebet ,arbejde“ er der en lang tradition for at forstå optimering af arbejde som minimering af arbejdsindsatsen, 
det vil sige reduktion af slid og tid i arbejdet, som det eksempelvis kommer til udtryk i ordsprog som ,work smarter, not harder“. Som sådan har der været fokus på at effektivisere arbejdsprocesser gennem udvikling af teknikker og tekniske kompetencer, først og fremmest i form af redskaber, som kan bidrage til, at arbejdet kan gøres lettere og hurtigere.

Denøkonomiske semantik udviklersig parallelt med udviklingen ogudbredelsen af pengeøkonomi og handel, hvorved der efterhånden kommer et stadig stærkere fokus på optimering af arbejdet med henblik på omkostningsminimering og maksimering af profit. Det er denne forståelse af optimering af arbejdet gennem omkostningsminimering, som først Taylor og siden michiganskolen knytter særligt stærkt an til. Hermed er der med udgangspunkt i denne økonomiske semantik blevet udviklet en række teknikker til optimering af arbejdet gennem effektiv udnyttelse af de menneskelige ressourcer, først og fremmest teknikker til effektivisering af arbejdsprocesserne, oplæring $\mathrm{i}$ arbejdsfunktioner og lignende (Price 2007, 2011).

Samtidig suppleres den oprindelige negative forståelse af arbejde med en mere positiv forståelse. Efterhånden betoner først filosoffer som John Locke og siden økonomer som Adam Smith og Karl Marx, at arbejde ikke nødvendigvis er en modsætning til frihed, men at mennesker tværtimod kan udfolde deres frihed gennem arbejde, nemlig friheden til at forme deres eget liv (Arendt 1958:96ff.). Marx betoner endda med polemisk brod vendt imod teologi og rationalistisk filosofi, at det er arbejdet og ikke Gud, der har skabt mennesket, og at det er arbejdet og ikke fornuften, der adskiller mennesket fra dyr (Marx 1969 [1847]). Gennem arbejdet kan mennesket forme sit liv, udfolde sin kreativitet, styrke sin identitet og etablere sociale relationer til andre mennesker. Hermed fremstår arbejde som noget positivt: Det forbindes med aktivitet og produktivitet i modsætning til passivitet og uproduktivitet og fremstår som sådan ikke i modsætning til, men tværtimod som et centralt element i et frit og værdifuldt liv. Det er denne forståelse af optimering af arbejdet gennem positive sociale relationer, som først human relations-paradigmet og siden harvardskolen knytter an til. Hermed er der med udgangspunkt i den økonomiske semantik også blevet udviklet en række teknikker til optimering af arbejdet gennem effektiv udvikling af de menneskelige ressourcer, først og fremmest teknikker til motivation gennem mulighed for indflydelse, samarbejde osv. (Price 2011).

Den økonomiske semantik giver således en sammensat forståelsesramme for arbejdet med at optimere arbejdet, der betoner såvel udnyttelse som udvikling af de menneskelige ressourcer i og for arbejdet.

I kommunerne er den økonomiske semantik markant til stede som overordnede, statslige krav om effektivitet og rationalisering, der er blevet skærpet siden 
1970'erne (Pedersen 2004). I HRM-politikkerne kommer det blandt andet til udtryk i en betoning af, at alle ansatte i en kommune skal udvise økonomisk sans og optimal brug af ressourcerne, inklusive deres egne menneskelige ressourcer (Herning Kommune 2007b:1). Den økonomiske semantik muliggør, at ansatte i kommunerne forstås og forstår sig selv som en værdifuld ressource, der skal $ø$ konomiseres med. Hermed legitimerer den, at en række HRM-tiltag og -teknikker med fokus på ressourceudnyttelse og -udvikling er blevet udbredt i kommunerne, herunder blandt andet resultatmålinger, incitamentsstrukturer osv. Men som det fremgår er den økonomiske semantik modsætningsfyldt og giver mulighed for at formulere konkurrerende bud på, hvordan man bedst økonomiserer med de menneskelige ressourcer (Townley 1994). Dette viser sig i tilbagevendende diskussioner om, hvorvidt økonomiske HRM-tiltag som resultatmålinger, procesmålinger og incitamenter bidrager til at udnytte eller udvikle de ansatte $\mathrm{i}$ kommuner og på andre arbejdspladser (Clematide \& Lassen 1999).

\section{En juridisk semantik om HRM}

Som nævnt udvikler den økonomiske semantik sig med udbredelsen af penge$ø$ konomi og handel. Hermed åbner den økonomiske semantik op for muligheden for andre semantikker. Man kan sige, at det efterhånden viser sig, at det kan betale sig at tage andre hensyn end rent økonomiske hensyn.

I første omgang viser det sig, at det kan betale sig at tage hensyn til love og regler $\mathrm{i}$ arbejdet. Med udviklingen af retsstaten og senere den moderne socialstat, der i stigende grad regulerer de samfundsmæssige forhold, bliver også arbejdsforhold i stigende grad reguleret gennem lovgivning og andre aftaler for og mellem arbejdsmarkedets parter. Hermed opstår der en juridisk semantik omkring arbejdet med at optimere arbejdet. Den juridiske semantik erstatter ikke den økonomiske semantik, men forudsætter den og bygger oven på den. Hvor den økonomiske semantik etablerer arbejdet som en økonomisk transaktion, er den juridiske semantik rettet mod at formalisere denne relation. Man kan således sige, at den økonomiske semantik etablerer en relation, som videreudvikles i den juridiske semantik.

I Danmark udtrykkes den juridiske semantik blandt andet gennem Septemberforliget fra 1899, hvor arbejdsmarkedets parter gensidigt tilskriver hinanden en række rettigheder og pligter. Når arbejdet beskrives juridisk, sættes der fokus på at formalisere arbejdet og arbejdet med at optimere arbejdet. Den juridiske semantik giver således grundlag for den moderne ansættelseskontrakt, der giver arbejdet en kontraktlig karakter med rettigheder og pligter, ydelser og modydelser. Arbejdsmæssige forhold som rekruttering og løn kan nu håndteres $\mathrm{i}$ 
formelle systemer med formaliserede kriterier, eksempelvis formel uddannelse og anciennitet. Ansættelser, forfremmelser og andre karriereperspektiver kan nu beskrives ved hjælp af formelle regler og rettigheder. Det er denne forståelse af optimering af arbejdet, som først Taylor og siden michiganskolen knytter an til, når de betoner formalisering og standardisering af arbejdsprocesser. I forlængelse heraf er der med udgangspunkt i en juridisk semantik blevet udviklet en række teknikker til optimering af arbejdet gennem formalisering af de menneskelige ressourcer, først og fremmest teknikker til standardisering af arbejdsprocesserne, funktionsbeskrivelser, kriterier for rekruttering, oplæring og belønning (Price 2007, 2011).

I en juridisk semantik handler optimering af de menneskelige ressourcer om formalisering, det vil sige om at identificere og kontrollere rettigheder og pligter $\mathrm{i}$ arbejdet. Det centrale omdrejningspunkt for den juridiske semantik er, gældende ret", det vil sige det, der er vedtaget som regler og andre juridisk bindende aftaler. Gældende regler er en kontrakt, som alle parter kan og skal holde sig til. Det, der ikke er gældende ret, er ikke relevant. Den juridiske semantik har således fokus på at begrænse mulighederne for, at uvedkommende forhold spiller en rolle. Blandt de uvedkommende forhold er først og fremmest personlige forhold. Det er forhold, der står uden for arbejdsretten, og som derfor ikke kan underlægges arbejdsretten. Det er forhold, der ikke kan gøres krav på eller stilles krav til i arbejdet. Men efterhånden udvikler den juridiske semantik sig igennem 1900-tallet parallelt med udviklingen af retsstaten og senere socialstaten, dels i form af nye regler og lovændringer, og dels i form af en udvikling fra formel ret til materiel ret. Hermed suppleres regler af normer og formålserklæringer, hvormed grundlaget for aftaler udvider sig fra at være formelt funderet i regler og hierarkier til at være materielt og konkret begrundet med henvisning til ikke bare formelle, men også uformelle og personlige kompetencer (Anderson 2004). Det er denne forståelse af optimering af arbejdet gennem personlige relationer, som først human relations-paradigmet og siden harvardskolen knytter an til. I forlængelse heraf er der med udgangspunkt $\mathrm{i}$ en juridisk semantik blevet udviklet en række teknikker til optimering af arbejdet gennem formaliseret udvikling af de menneskelige ressourcer, først og fremmest teknikker til motivation gennem formalisering af belønningssystemer, rettigheder om indflydelse og inddragelse (Price 2007, 2011).

Den juridiske semantik giver således, ligesom den økonomiske semantik, en sammensat forståelsesramme for arbejdet med at optimere arbejdet, men sætter fokus på de formelle forhold, der kan støtte op om såvel en effektiv udnyttelse som en positiv udvikling af de menneskelige ressourcer i og for arbejdet.

I kommunerne er den juridiske semantik tydelig som en overordnet ramme omkring ansættelseskontrakter, rettigheder og pligter. I HRM-politikkerne kommer det blandt andet til udtryk i betoningen af, at en kommune er en politisk 
styret organisation, og at tiltag besluttes i et formelt system af medbestemmelse og medindflydelse, det såkaldte MED-system (Sorø Kommune 2007:1). Den juridiske semantik muliggør, at ansatte i kommunerne forstås og forstår sig selv som juridiske personer eller ressourcer med rettigheder og pligter, der kan formaliseres i kontrakter og standarder. Hermed legitimerer den, at en række HRM-tiltag og -teknikker med fokus på regulering og formalisering er blevet udviklet og udbredt i kommunerne, blandt andet ansættelseskontrakter, formelle bedømmelseskriterier, rettigheder og pligter. Men som det fremgår, er også den juridiske semantik modsætningsfyldt og giver mulighed for at formulere konkurrerende bud på, hvordan man bedst regulerer og formaliserer de menneskelige ressourcer (Townley 1994). Dette viser sig som tilbagevendende diskussioner om, hvorvidt konkrete juridiske HRM-tiltag i form af formelle kontrakter eller standardiserede procedurer bidrager til at udnytte eller udvikle de ansatte i kommuner og på andre arbejdspladser (Andersen 2004).

\section{Den emotionelle semantik om HRM}

Som nævnt udvikler den juridiske semantik sig med udviklingen i socialstaten, hvormed den bliver åben for koblinger til andre semantikker. Som sådan bliver det efterhånden en ret (og pligt) at tage andre end rent formelle hensyn såsom hensyn til personlige og emotionelle forhold $i$ arbejdet.

Det mest iøjnefaldende udtryk for dette er, at temaer som trivsel, engagement, interesse og motivation dukker op som HRM-temaer, der gives betydning i arbejdet med at optimere arbejdet. Hermed opstår der en emotionel semantik om HRM, der knytter an til såvel den økonomiske som den juridiske semantik, men samtidig forskyder betydningen af centrale begreber. Som sådan træder den emotionelle semantik ikke i stedet for andre semantikker, men forudsætter dem og supplerer dem. Hvor kompetence i en økonomisk semantik bliver forstået som arbejdskraft og i en juridisk semantik bliver forstået som formelle og funktionelle kompetencer, åbner en emotionel semantik op for at betragte personlige kompetencer - herunder kompetencer i forhold til følelser og personlighed som relevante $\mathrm{i}$ og for arbejdet med at optimere de menneskelige ressourcer $\mathrm{i}$ arbejdet. Hermed opløser den emotionelle semantik grænsen mellem det sagligt og det personligt relevante. Saglige temaer kan ikke holdes adskilt fra personlige temaer (Anderson 2004). Genstand for læring og udvikling er ikke alene faglige færdigheder, men også personlige færdigheder som at lære sig selv at kende og lære at omgås andre. Emotionelle og personlige ressourcer gøres til et aktiv i forbindelse med arbejdet, ligesom arbejdspladsens aktiviteter gøres til ressourcer, der kan berige det personlige liv. 
Det er denne emotionelle semantik, som først human relations-paradigmet og siden harvardskolen knytter særligt stærkt an til. I forlængelse heraf er der med udgangspunkt i en emotionel semantik blevet udviklet en række teknikker til optimering af de menneskelige ressourcer med fokus på personligt engagement, først og fremmest teknikker til at skabe engagement og trivsel gennem alsidighed og udvikling i arbejdsopgaverne, teamsamarbejde osv. (Price 2007, 2011). Men også Taylor og i særlig grad michiganskolen knytter an til den emotionelle semantik, idet det betones, at der er en personlig og emotionel dimension ved udvælgelse, vurdering, fastholdelse, belønning og kompetenceudvikling af medarbejderne. I forlængelse heraf er der med udgangspunkt i en emotionel semantik blevet udviklet en række teknikker til mere effektiv udnyttelse af de menneskelige ressourcer i arbejdet med fokus på personligt engagement og trivsel, først og fremmest teknikker til trivselsmåling, personlighedstests, teamudvikling osv. (ibid.). Den emotionelle semantik giver således en sammensat forståelsesramme for arbejdet med at optimere arbejdet med fokus på de emotionelle og personlige forhold, der er afgørende for såvel en effektiv udnyttelse som en positiv udvikling af de menneskelige ressourcer i arbejdet.

Den emotionelle semantik med fokus på engagement og udvikling er markant til stede i kommunernes HRM-politikker. Eksempelvis betoner Sorø Kommunes visionspapir, at kommunen har fokus på ,det gode arbejdsliv og den attraktive arbejdsplads“ og derfor sætter fokus på, „hvad der fremmer og hæmmer glæden ved at gå på arbejde, og hvad der virker engagerende og meningsfyldt" (Sorø Kommune 2007:1). Tilsvarende betoner Herning Kommune, at kommunen ønsker at være „en god arbejdsplads“ med ,et godt samarbejde“ og „balance mellem arbejdsliv og privatliv" (Herning Kommune 2007b:1). Den emotionelle semantik muliggør, at ansatte i kommunerne forstås og forstår sig selv som emotionelle ressourcer, der kan udfoldes, både på og uden for arbejdet. Det er ressourcer eller kompetencer, der så at sige ,vender indad“ mod individet selv. Hermed legitimerer den emotionelle semantik, at en række HRM-tiltag og teknikker med fokus på de ansattes personlige engagement er blevet udviklet og udbredt i kommunerne, blandt andet supervision, trivsel og teamudvikling. Men også den emotionelle semantik er modsætningsfyldt og giver mulighed for at formulere konkurrerende bud på, hvordan man bedst mobiliserer og engagerer de menneskelige ressourcer (Townley 1994). Dette viser sig som tilbagevendende diskussioner om, hvorvidt konkrete HRM-tiltag i forhold til personligt engagement eller personlig trivsel bidrager til at udnytte eller udvikle de ansatte i kommuner og på andre arbejdspladser (Andersen 2004). 


\section{Den pædagogiske semantik om HRM}

Inden for de seneste årtier har der været stigende fokus på læring og udvikling, både i organisationer og i samfundet i det hele taget (Andersen 2004). Hermed er der efterhånden blevet udviklet en pædagogisk semantik om arbejdet med at optimere de menneskelige ressourcer i arbejdet. Det mest iøjnefaldende udtryk for dette er, at temaer som livslang læring, omskoling, efteruddannelse, videreuddannelse og lignende dukker op som HRM-temaer, der gives betydning $\mathrm{i}$ arbejdet med at optimere arbejdet (Bovbjerg 2001). Læring og uddannelse er ikke længere noget, der afsluttes. Mange tager en uddannelse, men ingen er længere uddannet i betydningen ,dannet-ud“, det vil sige færdigformet. I et samfund i udvikling og i organisationer, der forandrer sig, skal alle være i udvikling. Det er blevet et mantra blandt konsulenter og organisationsudviklere, at hvis man ikke er i udvikling, er man de facto i afvikling. Den pædagogiske semantik knytter meget let an til de andre semantikker, men forskyder samtidig betydningen af centrale begreber (Andersen 2004). I den pædagogiske semantik anskues kompetence ikke (længere) som faste og kendte egenskaber og funktioner, der udvikles og udnyttes optimalt, men er først og fremmest et potentiale, der kontinuerligt skal bearbejdes (Andersen 2012).

I en pædagogisk semantik handler optimering af de menneskelige ressourcer om fortsat udvikling i og af arbejdet, først og fremmest gennem kontinuerlig læring og kompetenceudvikling, hvor læring og udvikling ikke tænkes adskilt fra, men tværtimod tæt forbundet med arbejdet. Idealet er en medarbejder, der er fleksibel og omstillingsparat (Bovbjerg 2001). Specialisering kan nu blive betragtet som et potentielt problem, fordi det reducerer omstillingsparatheden og fleksibiliteten. Genstand for læring og udvikling er ikke alene bestemte faglige færdigheder eller personlige egenskaber, men også selve det at lære at lære. Det er ikke muligt at definere de aktuelle og relevante kompetencer og kompetencebehov. Derfor må man først og fremmest have kompetence til kompetenceudvikling (Andersen 2004). Hermed tømmes kompetencebegrebet for alt indhold, men peger blot på sig selv. At være kompetent er at kompetenceudvikle sig selv. Den vigtigste færdighed bliver at betragte sig selv som et potentiale, der kan udvikle sig. Ansatte skal kunne forholde sig til sig selv som kompetence og kompetencepotentiale. Og ledelse forskyder sig fra instruktion og uddeling af opgaver til inspiration og opfordring til at tage initiativ. Ledelse skal give muligheder: muligheder for udvikling, for udfordring, for fleksibilitet, for initiativ.

HRM-feltet har haft meget let ved at indoptage den pædagogiske semantik. Den harmonerer godt med den betoning af oplæring og kompetenceudvikling, som man finder hos såvel Taylor og michiganskolen som human relations-paradigmet og harvardskolen. Efterhånden er der blevet udviklet en række avancerede 
teknikker til optimering af de menneskelige ressourcer med fokus på læring og kompetenceudvikling med henblik på såvel effektiv udnyttelse som positiv udvikling af de menneskelige ressourcer, først og fremmest teknikker og praksisser som medarbejderudviklingssamtaler, coachingsamtaler osv. (Price 2007, 2011). Også den pædagogiske semantik giver således en sammensat forståelsesramme for arbejdet med at optimere arbejdet med fokus på de pædagogiske eller læringsmæssige forhold, der er afgørende for såvel en effektiv udnyttelse som en positiv udvikling af de menneskelige ressourcer i arbejdet.

Den pædagogiske semantik med fokus på engagement og udvikling er tydelig i HRM-politikkerne i Sorø og Herning Kommuner. Eksempelvis betoner Sorø Kommune, at kommunen er en arbejdsplads i udvikling, og at denne udvikling fordrer, at alle deltager i udviklingsprocessen, fordi alle ansatte „har en masse ideer og tanker om“, hvordan arbejdspladsen og -opgaverne kan udvikles (Sorø Kommune 2007:1). Tilsvarende betoner Herning Kommune, at kommunen ønsker at være en ,udviklende arbejdsplads" (Herning Kommune 2007b:1). Endvidere betones det, at „kompetenceudvikling er et væsentligt element i bestræbelsen på at udvikle attraktive arbejdspladser i Herning Kommune, hvor vi kan udvikle og fastholde os selv og hinanden" (Herning Kommune 2007a: 1). Den pædagogiske semantik gør det muligt, at ansatte i kommunerne forstås og forstår sig selv som pædagogisk potentiale, der kontinuerligt kan (og skal) udvikles både på og uden for arbejdet. Hermed legitimerer den, at en række HRM-tiltag og -teknikker med fokus på de ansattes læring er blevet udviklet og udbredt i kommunerne, blandt andet coaching, medarbejderudviklingssamtaler osv. Men hvad og hvordan der skal læres, er åbne spørgsmål. Den pædagogiske semantik er således lige så modsætningsfyldt som de øvrige HRM-semantikker og giver mulighed for at formulere konkurrerende bud på, hvordan man bedst kompetenceudvikler de menneskelige ressourcer (Townley 1994). Dette viser sig som tilbagevendende diskussioner om, hvorvidt pædagogiske HRM-tiltag i forhold til læring eller kompetenceudvikling bidrager til at udnytte eller udvikle de ansatte i kommuner og på andre arbejdspladser (Clematide \& Lassen 1999).

\section{Konklusion: Optimering i og af HRM}

Artiklen har sat fokus på arbejdet med at optimere arbejdet, som dette beskrives og bedrives i HRM-principper og -politikker. HRM er blevet et centralt, strategisk fokus i de senere år, i takt med at de menneskelige ressourcer i virksomheder og 
organisationer er blevet betonet som de mest dyrebare (og dyreste) ressourcer. Til at håndtere dette arbejde med at optimere arbejdet har mange virksomheder og organisationer etableret HRM-afdelinger, formuleret HR-strategier og andre HR-politikker, der beskriver ambitioner og intentioner i arbejdet med at optimere de menneskelige ressourcer.

I artiklen har jeg beskrevet, hvordan HRM-litteraturen typisk skelner mellem to forskellige strategier i arbejdet med at optimere arbejdet: dels en ,hård“ strategi, som søger at optimere de menneskelige ressourcer i organisationer gennem rationalisering af arbejdsprocesser, og dels en „blød“ strategi, som søger at optimere de menneskelige ressourcer gennem kontinuerlig udvikling, inspiration og innovation. Denne modstilling kan tjene til at betone en grundlæggende modsætning i HRM-feltet, men en ensidig fokusering på denne modstilling overser dog, at HRM-feltet er langt mere komplekst og sammensat. Semantikkerne og teknikkerne i strategierne er blevet forskudt, så de efterhånden omfatter stadig flere områder af de menneskelige ressourcer.

Artiklen viser således, at HRM-feltet er et komplekst felt med forskellige forståelsesrammer for arbejdet med at optimere arbejdet og for menneskers selvforståelse i det hele taget. Jeg har identificeret en forskydning af arbejdet med at optimere arbejdet igennem fire forskellige semantikker: en økonomisk, en juridisk, en emotionel og en pædagogisk semantik, der er blevet kondenseret $\mathrm{i}$ begrebet om ,optimering“ af arbejdet. Disse semantikker tilbyder betydningsfulde begreber og praktiske greb i forhold til arbejdet med at optimere de menneskelige ressourcer i arbejdet. Som en økonomisk aktivitet eller relation har arbejdslivet traditionelt været tematiseret i økonomisk semantik med fokus på, hvad der kan betale sig. Med retsstatens etablering og udvikling suppleres den økonomiske semantik efterhånden af en juridisk semantik med fokus på rettigheder og pligter. Denne suppleres efterhånden med en emotionel semantik med fokus på engagement og ansvarlighed. Og i de seneste år er arbejdslivet også blevet beskrevet i en pædagogisk semantik med fokus på læring og udvikling. Disse semantikker tilbyder hver især et sprog, hvori arbejdet med at optimere de menneskelige ressourcer formuleres og formes. Som sådan tilbyder de et sprog for arbejdet med at optimere arbejdet, der kan få store konsekvenser for forståelsen af, hvad det vil sige at være et menneske, nemlig en ressource, der kan optimeres i og for arbejdslivet. 


\section{Noter}

1. Betegnelsen HRM har ikke en almen dansk oversættelse, men kan oversættes til ,personaleledelse" i bred forstand.

2. Disse betegnelser har heller ikke almene danske oversættelser, men kan oversættes til „højpræstation“ og „højengagement“ HRM.

Søgeord: HRM, arbejde, policy, semantik, teknik

\section{Litteratur}

Andersen, Niels Åkerstrøm

$2004 \quad$ Ledelse af personlighed. Om medarbejderens pædagogisering. I: D. Pedersen (red.): Offentlig ledelse i den moderne managementstat. Side 241-67.

Frederiksberg: Samfundslitteratur.

2012 Flygtige forhold. Om ledelse af medarbejdere mellem pædagogik, kærlighed og leg. København: Hans Reitzels Forlag.

Applebaum, Herbert

1992 The Concept of Work. Ancient, Medieval and Modern. New York:

New York Press.

Arendt, Hannah

1958 The Human Condition. Chicago: University of Chicago Press.

Bakka, Jørgen F. \& Eigil Fivelsdal

2002 Organisationsteoriens klassikere. Fra Taylor og Weber til Simon og Drucker.

København: Handelshøjskolens Forlag.

Barber, Benjamin

2008 Consumed. How Markets Corrupt Children, Infantilize Adults, and Swallow Citizens Whole. New York: W.W. Norton.

Beer, Michael, Bert Spector, Paul Lawrence, Quinn Mills \& Richard Walton (eds).

1985 Human Resource Management. A General Manager's Perspective. New York: Free Press.

Bennis, Warren \& Burt Nanus

1985 The Strategies for Taking Charge. New York: Harper and Row.

Blowfield, Michael

2013 Business and Sustainability. Oxford: Oxford University Press.

Bovbjerg, Kirsten Marie

2010 Følsomhedens etik. Højbjerg: Hovedland.

Bovbjerg, Kirsten Marie, Jakob Krause-Jensen, Susan Wright, Grethe Brorholt \& Leif Moos

$2011 \quad$ Nye ledelsesrationaler i offentlige organisationer. I: K.M. Bovbjerg (red.):

Motivation og mismod. Det nye arbejdslivs dilemmaer. Side 17-42. København:

Aarhus Universitetsforlag.

Bovbjerg, Kirsten Marie (red.).

2011 Motivation og mismod. Det nye arbejdslivs dilemmaer. København:

Aarhus Universitetsforlag. 
Clematide, Bruno \& Morten Lassen

1999a Udvikling med indhold. I: B. Clematide \& M. Lassen (red.): Virksomheden og det udviklende arbejde. Et kritisk blik. Side 1-18. Frederiksberg: Samfundslitteratur.

Clematide, Bruno \& Morten Lassen (red.)

1999b Virksomheden og det udviklende arbejde. Et kritisk blik. Frederiksberg:

Samfundslitteratur.

Cunliffe, Ann

2009 A Very Short, Fairly Interesting and Reasonably Cheap Book about Management. London: Sage.

Davies, Norman

1996 Europe. A History. A Panorama of Europe, East and West, from the Ice Age to the Cold War, from the Urals to Gibraltar. New York: Oxford University Press.

Drucker, Peter

1973 Management. Task, Responsibilities, Practices. New York: Harper \& Row.

Durning, Alain

1992 How Much is Enough? The Consumer Society and the Future and the Earth.

New York: W.W. Norton.

Fombrun, Charles, Noel Tichy \& Mary Ann Devanna (eds)

1984 Strategic Human Resource Management. New York: John Wiley \& Sons.

Grint, Keith

2005 The Sociology of Work. Cambridge: Polity Press.

Herning Kommune

2007a Kompetenceudvikling af medarbejdere. www.herning.dk.

2007b Vision og værdier for Herning Kommune. www.herning.dk.

2007c Herning Kommunes arbejdsmiljøpolitik. www.herning.dk.

Hyman, Richard

2006 Marxist Thought and the Analysis of Work. In: M. Korczynsky, R. Hodson \&

P.K. Edwards (eds): Social Theory at Work. Pp. 26-55. Oxford: Oxford University Press.

Korczynsky, Marek, Randy Hodson \& Paul Edwards (eds)

2006 Social Theory at Work. Oxford: Oxford University Press.

Krause-Jensen, Jakob

2010 Flexible Firm. Design of Culture at Bang \& Olufsen. New York: Berghahn Books.

Legge, Karen

2005 Human Resource Management, Rhetorics and Realities. New York: Palgrave MacMillan.

Leidner, Robin

2006 Identity and Work. In: M. Korczynsky, R. Hodson \& P.K. Edwards (eds): Social Theory at Work. Pp. 424-63. Oxford: Oxford University Press.

Lundberg, Ulf \& Cary L. Cooper

2010 The Science of Occupational Health. Stress, Psychobiology and the New World of Work. Oxford: John Wiley \& Sons. 
Lystbæk, Christian T.

2011 Ledelse af læring af ledelse. I: P. Helth (red.): Ledelse og læring i praksis.

Frederiksberg: Samfundslitteratur.

Machin, Stephen

2006 The Economic Approach to Analysis of the Labour Market. In: M. Korczynsky et al. (eds): Social Theory at Work. Pp.182-207. Oxford: Oxford University Press.

Marx, Karl

1969 [1847] Die deutsche Ideologie. In Werke, III. Berlin: Dietz Verlag.

Muchinsky, Paul M.

2008 Psychology Applied to Work. An Introduction to Industrial and Organizational Psychology. Summerfield: Hypographic Press.

Paauwe, Jaap, David Guest \& Patrick Wright (eds)

2013 HRM and Performance. Achievements and Challenges. Sussex: John Wiley \& Son.

Pedersen, Dorthe (red.)

2004 Offentlig ledelse i den moderne managementstat. Frederiksberg:

Samfundslitteratur.

Price, Alan

2007 Human Resource Management in a Business Context. New York:

Cengage Learning.

2011 Human Resource Management. New York: Cengage Learning.

Schultz, Duane \& Ellen Schultz

2009 Psychology and Work Today. Florida: Pearson.

Shore, Chris \& Susan Wright (eds).

$1997 \quad$ Anthropology of Policy. London: Routledge.

Sorø Kommune

2007 Det gode arbejde - den attraktive arbejdsplads. www.soroe.dk.

Storey, John

1992 Development in the Management of Human Resources. Oxford: Blackwell.

Swanson, Richard \& Elwood Holton

2009 Foundations of Human Resource Development. San Francisco: BK Publ.

Taylor, Frederick W.

1903 Shop Management. New York: American Society of Mechanical Engineers.

1911 The Principles of Scientific Management. New York: Harper \& Brothers.

Townley, Barbara

1994 Reframing Human Resource Management. Power, Ethics and the Subject at Work. London: Sage Publ.

Vallas, Steven, William Finlay \& Amy Wharton

2009 The Sociology of Work. Oxford: Oxford University Press. 